\title{
Towards a Periodical
}

\section{and Monograph Price Index}

This paper examines the various steps and intricacies involved in tailoring a periodical and monograph price index to a university library and looks at a number of issues librarians are wrestling with in an attempt to balance their acquisition budgets. The authors describe the difficulties involved in applying a simple methodology such as a price index when the database is not geared to active decision making. Findings related to the shifting of funds from books to periodicals, the price-increase differential between domestic and foreign titles, and prices paid by the library and those advertised by publishers are presented.

$\mathrm{T}$ vent the wheel, as the field of economics has long discovered how to construct and apply price indexes to various commodities, including library materials. However, publishers and particularly institutional librarians know that book and serial price indexes generally available to them must be used with caution because they represent national price patterns and should, under no circumstances, be assumed to depict individual library characteristics. ${ }^{1}$

\section{REVIEW OF LITERATURE Library Role in Jeopardy}

Few would deny the increasing importance of information in our society as half of the working population is involved with information industries representing annual expenditures of one-third of a trillion dollars. ${ }^{2}$ This affluence of information coupled with tight budgets and rising library materials has

Charles H. Bélanger is director, Office of Institutional Research, and Lise Lavallée is research economist, Office of Institutional Research, Université de Montréal, Québec. The authors express special thanks to the library administration and particularly to the Technical Services Division for their collaboration. A note of gratitude is also extended to J. Courval for her assistance in the data collection. The views expressed do not necessarily reflect those of the Office of Institutional Research. put great stress on major research library managers. ${ }^{3}$ In fact, constituents of the university community still expect them to make libraries vital and dynamic centers of inspiration, information, and advanced research with an eroding dollar budget. 4,5

Traditionally, universities have been allocating approximately 5 percent of their educational and general budget to library operations $;$, 7 however, this percentage distribution appears to have been used more as a convenient device to divide up funds than as the result of an evaluation of actual library needs. When institutional budgets were on the rise, library managers enjoyed years of expanding collections. ${ }^{8}$ Today, they face a completely different set of circumstances: (a) most budgets have been frozen; (b) price increases of books and serials have gone up at a much higher rate than other university costs $;^{9,10,11}$ and (c) decisions are being made on serial subscription cuts and monograph purchase curtailment. ${ }^{12,13}$ This situation leads to the obvious question, How is a library supposed to remain an adequate and equitable interface between users and the ever-increasing production of literature when there is not enough money to meet the commitments of the previous year?

\section{Progress in Bibliometrics}

A survey of library science literature indicates a keen interest by library professionals 
in quantitative analysis since the publication of the Clapp-Jordan formula. ${ }^{14}$ The main contribution of that formula was to introduce the notion of library materials allocation as a function of the characteristics of the curriculum, faculty, students, and other similar factors. From that point on, followers have been hard at work identifying and refining the variables most likely to result in equitable funding. Departmental library usage and literature size were first considered by McGrath, Huntsinger, and Barber. ${ }^{15}$ The importance that society and the university gave to the work of a department, as well as its size and composition, was established by Goyal. ${ }^{16}$ McGrath gave strong indications that the various features of the curriculum and the academic disciplines should be a heavily weighted factor. ${ }^{17,18}$ Historical inequities and collection evaluations are also frequently mentioned as subjective formula variables.

Besides budgeting and allocation formulas, several other instruments designed to suggest directions in the decision-making process have become available. Just briefly, it is worth mentioning cost-effective analyses of library resource allocation, ${ }^{10,20,21}$ forecasting library growth rate techniques, ${ }^{22,23}$ literature obsolescence scale, ${ }^{24}$ and rank-order distributions of importance and usefulness of periodicals derived from citation analysis. ${ }^{25}$ As Pierce accurately pointed out, these statistical techniques have generally been met with a fair amount of skepticism because department chairpersons felt there was a danger that the results would be viewed as final decisions instead of guides. ${ }^{26}$

\section{Measurement of Price Increases}

In addition to the quantitative instruments mentioned, library managers have made extensive use of price indexes and studies to justify and allocate budgets. There are four commonly known periodical price studies: the first is the Clasquin or Faxon study, ${ }^{27}$ published annually in October and reflecting the price-increase trends of periodicals published in the United States in the past three years. The second is the Blackwell Index, and is published each year in the May issue of the Library Association Record. ${ }^{28}$ Since Blackwell is a British agency, all prices are reported in pounds sterling only and, contrary to the annual Faxon study, the Blackwell Index includes foreign titles. The currency conversion problem, however, makes it less readily usable. The third periodical price study, the Widener Periodical Price Index, was recently developed by Williams in order to have a better grasp on the price increases by country of origin. ${ }^{29}$ Finally, Brown and Phillips make an annual update of price increases of American periodicals for as far back as a ten-year period. ${ }^{30}$ On the monograph side, price studies are generally available under the form of yearly increases; Publishers Weekly carries such comparative statistics. ${ }^{31}$

No matter how useful these figures are to depict price patterns, there is ample justification for preparing local indexes. The local mix of academic disciplines in conjunction with the differential rates of inflation across disciplines is an obvious reason. Statistics compiled by Brown and Phillips show that the average subscription price of an American periodical last year was $\$ 30.37 . .^{32}$ Further scrutiny indicates that chemistry and physics journals averaged $\$ 118.33$ as compared to $\$ 14.67$ for history. The proportion between domestic and foreign titles is also a determining factor; a case in point is the Université de Montréal. As one of the largest universities in Canada offering myriad academic programs, the Université de Montréal also happens to be a French-speaking school. Therefore, not only does it have to import, like most Canadian research universities, a great deal of the scientific literature from outside the country, but it must also try to accommodate students with a certain number of French reference books and periodicals whenever feasible. These conditions increase immensely the probability of dealing with agents, paying more for postal services, and being at the short end of the currency conversion business, especially when the Canadian dollar stands at an unfavorable position visà-vis the already devaluated U.S. dollar.

\section{METHODOLOGY}

A typical price index is generally designed by comparing the observed price of a commodity at a given period $\left(t_{1}, t_{2} \ldots, n\right)$ with the price of the same commodity at an agreed-upon base year $\left(t_{0}\right)$. The construction of such an index necessitates a fundamental decision regarding the homogeneity of the 
commodity throughout the years. In other words, it must be ascertained that price variations to produce an item are directly caused by fluctuating costs alone and are not the result of another mixture of components being affected by different rates of inflation in the production process of that item. This decision is often an arduous one because of the difficulty involved in identifying the principal component goods and in gathering hard data on them. Can one assert that the first edition of a book published in 1970 represents the same commodity ten years and three editions later? This type of inherent problem accounts for the limited maneuvering range one is confronted with in this kind of study.

Three major steps were involved in the data collection. First, it was necessary to reconstruct the financial picture of the university, the library, and the acquisition department, and to establish relationships among them in terms of their relative importance and their annual evolution for the last ten years (base year $=1971$ ). This process also served to determine the number of titles bought by subject area and the amounts of money used.

Second, a sample of subject areas and titles had to be selected. Ideally, all subject areas and titles should have been included, but this route proved to be highly impractical since the needed information had to be collected manually. Therefore, it was decided that the sample should represent: (1) the four countries that were the major sources of titles, namely, Canada, France, Great Britain, and the United States; (2) the four main categories under which subject areas were clustered, that is, health sciences, humanities, pure sciences, and social sciences; and (3) the subject areas that constituted major expenditures by the acquisition department. The library acquisition department staff was then asked to provide at least five periodical titles on the one hand for each of the twenty-four selected disciplines in each of the four countries. This initial sample selection of 960 titles, split equally between periodicals and monographs, was judgmental in the sense that all titles chosen by the acquisition staff were considered essential reference instruments to students in the subject areas. Usage and content were the key elements in the defi- nition and application of the term "essential."

Third, the differential between the publishers' advertised prices and prices actually paid by the library was of significant interest. This information was gathered from catalogs of publishing companies and paymenthistory records of the library. ${ }^{33}$ However, catalogs such as Ulrich's are not necessarily reliable since prices are not always updated. To cover for that possible loophole, prices were checked against those directly advertised inside most periodicals. Many invoicerelated difficulties led to the elimination of a number of titles. Periodicals published less frequently than semiannually were dropped and so were the titles not paid on the annual subscription basis. Finally, when all technical difficulties were resolved, a sample of 256 periodical titles distributed evenly across the cells was left. Aggregates of the total cost of the sixteen periodicals represented in each cell were computed in order to establish a comparison between publisher and library paid prices. Disparities between 1971 and 1979 prices were measured with a price index, on the one hand for publisher prices, and on the other hand for library paid prices.

Although the authors intended to cover both periodicals and monographs, it became obvious, during the data collection, that the lack of a manageable and consistent database on monographs would lead only to unreliable and meaningless results. The main problem arose from the hidden costs of book prices. Sometimes invoices did not indicate whether insurance, postage, and discount dollar figures were already mixed with the actual book price. The size of purchase orders was another imponderable factor influencing the price of a book; by and large, the bigger the purchase order, the less expensive the book. Finally, the same book was often marketed by different companies from one year to the next. All these obstacles led to an imbroglio. Therefore, a more extensive case is made with periodicals while monographs are not treated in detail, but simply in very general terms.

\section{Results}

The dollar figures presented in table 1 indicate that in the last nine years, the university 
educational and general budget has more than tripled to reach an index of 345 as compared with fiscal base year 1971-72. This percentage yield represents a yearly average increase of 43 percent in inflated dollars. This growth rate might, at first sight, appear phenomenal; however, during the same period, head-count enrollment went from 18,000 to 28,000 , with large contingents of students registering in the more expensive professional programs. The library (329) and acquisition (335) budgets kept a slightly slower pace, although similar, than the university budget. Observed dollar amounts allocated for all library expenditures varied between 5 and 6 percent, which is about the level of funding usually reported in the literature. Out of this total library budget, the share used to purchase periodicals and monographs ranged from 20 to 24 percent.

A rapid overview of table 2 leads to a rather typical finding. Financial resources were invested in periodicals at a much higher rate (431) over the years than was the case for monographs (264). In fact, there was a complete reversal of the relative proportion of funds spent for periodical subscriptions and book purchases in the last five years. Although periodicals are now receiving the larger share of the new distribution, it is nothing short of astonishing to note that the number of periodical titles has begun to decrease along with the sharp downtrend of monograph titles (79).

When one examines the periodical price index figures assembled in table 3 , the multifaceted problem of subscription costs becomes more obvious. The price of domestic journals has risen at a substantially lower pace than that of foreign titles. The fact that this finding has been corroborated by many authors in the literature is of very little comfort because the Université de Montréal Library buys an estimated minimum of 75 percent of its periodicals from non-Canadian sources, and over 50 percent from Europe. ${ }^{34,35}$ Price increases have been particularly sharp for publications originating in France and Great Britain, let alone certain publications of very specialized fields, mainly in the health sciences, imported from robust-currency countries such as Holland, Switzerland, and West Germany. By all means, the reported figures must be interpreted as conservative estimates. The variation in inflation among subject-matter categories exhibits differential rates. Canadian price indexes are quite homogeneous while those of the three other countries fluctuate considerably across categories.

Table 3 also shows price indexes of periodicals as reflected by prices advertised by publishers and prices actually paid by the library for the same titles. This issue is generally receiving marginal attention in the literature despite huge differentials between the two sets of prices. Evidence demonstrates that the library is picking up a much larger bill than the publishers' price rates would lead one to believe. For illustrative purposes, French humanities periodicals have an index yield of 378 , or 42 percent, per year according to the publishers' posted prices, while the same commodity recorded a price index of 490 for the library over a nine-year period, or an annual average of 61 percent. The allocation index that represents the evolution of dollar allotment by funding category was found to be generally higher than the indexes arrived at for each of the four countries investigated. This trend is not unduly alarming since the base-year data are not the same. A more direct relationship would have been possible if the library had had available records showing the relative proportion of periodicals bought by country of origin in each academic discipline.

\section{Discussion of Results}

The astronomical inflationary rate suffered by most academic libraries in the past decade has left librarians searching for logical, though often elusive, solutions. Many librarians have claimed that they were "the victims of discriminatory pricing stratagems" because libraries were charged more than individuals for subscriptions. ${ }^{36}$ That libraries are the most affluent group of buyers available seems to be a well-established fact among publishers, and not much relief should be expected there. According to White, who has studied the profit taken by commercial publishers of scholarly journals, there has been no evidence to substantiate unreasonable operating profits. ${ }^{37}$ The Canadian Consumer Price Index (CPI) for library 


\section{TABLE 1}

UNIVERSITY, LibRARY, AND ACQUISITION BUdGETS (\$CAN.)

UNIVERSITÉ DE MONTRÉAL

\begin{tabular}{|c|c|c|c|c|c|c|c|c|}
\hline \multirow[b]{2}{*}{$\begin{array}{l}\text { Fiscal } \\
\text { Year }\end{array}$} & \multicolumn{2}{|c|}{$\begin{array}{l}\text { University Educational } \\
\text { and General Budget }\end{array}$} & \multicolumn{2}{|c|}{$\begin{array}{l}\text { Library } \\
\text { Budget }\end{array}$} & \multicolumn{2}{|c|}{$\begin{array}{c}\text { Acquisition } \\
\text { Budget }\end{array}$} & \multirow[b]{2}{*}{$\frac{\text { Library \$ }}{\text { University\$ }}$} & \multirow[b]{2}{*}{$\frac{\text { Acquisition } \$}{\text { Library } \$}$} \\
\hline & $\begin{array}{c}\text { Amount } \\
(\$ 000)\end{array}$ & Index & $\begin{array}{c}\text { Amount } \\
(\$ 000)\end{array}$ & Index & $\begin{array}{c}\text { Amount } \\
(\$ 000)\end{array}$ & Index & & \\
\hline $\begin{array}{l}1971-72 \\
1975-76 \\
1979-80\end{array}$ & $\begin{array}{r}48,600 \\
99,500 \\
167,500\end{array}$ & $\begin{array}{l}100 \\
205 \\
345\end{array}$ & $\begin{array}{l}2,910 \\
5,150 \\
9.570\end{array}$ & $\begin{array}{l}100 \\
177 \\
329\end{array}$ & $\begin{array}{r}600 \\
1,250 \\
2,010\end{array}$ & $\begin{array}{l}100 \\
208 \\
335\end{array}$ & $\begin{array}{l}6.0 \\
5.2 \\
5.7\end{array}$ & $\begin{array}{l}20.6 \\
24.3 \\
21.0\end{array}$ \\
\hline
\end{tabular}

TABLE 2

Periodicals and Monographs

Evolution OF BUdGET AND NUMBER OF TITLES

\begin{tabular}{|c|c|c|c|c|c|c|c|c|c|c|}
\hline \multirow[b]{2}{*}{$\begin{array}{l}\text { Fiscal } \\
\text { Year }\end{array}$} & \multicolumn{4}{|c|}{ Acquisition Budget } & \multicolumn{2}{|c|}{$\begin{array}{c}\text { Acquisition } \\
\text { Budget }\end{array}$} & \multirow[b]{2}{*}{$\begin{array}{l}\text { Per. } \\
(000)\end{array}$} & \multicolumn{2}{|c|}{ Number of Titles } & \multirow[b]{2}{*}{ Index } \\
\hline & $\begin{array}{l}\text { Per. } \\
(\$ 000)\end{array}$ & Index & $\begin{array}{l}\text { Mon. } \\
(\$ 000)\end{array}$ & Index & Per. \% & Mon. \% & & Index & $\begin{array}{l}\text { Mon. } \\
(000)\end{array}$ & \\
\hline $1971-72$ & 255 & 100 & 345 & 100 & 43 & 57 & 9.5 & 100 & 25.4 & 100 \\
\hline $1975-76$ & 555 & 218 & 695 & 201 & 44 & 56 & 13.2 & 139 & 25.0 & 99 \\
\hline $1979-80$ & 1,100 & 431 & 910 & 264 & 55 & 45 & 12.6 & 133 & 20.0 & 79 \\
\hline
\end{tabular}


TABLE 3

Periodical Price Indexes* (\$Can.)

A Comparison between Publisher and Libraty Paid Prices

\begin{tabular}{|c|c|c|c|c|c|c|c|c|c|}
\hline \multirow[b]{2}{*}{ Categories } & \multicolumn{2}{|c|}{$\begin{array}{l}\text { Canada } \\
\text { Index }\end{array}$} & \multicolumn{2}{|c|}{$\begin{array}{l}\text { France } \\
\text { Index }\end{array}$} & \multicolumn{2}{|c|}{$\begin{array}{c}\text { Great } \\
\text { Britain Index }\end{array}$} & \multicolumn{2}{|c|}{$\begin{array}{c}\text { USA } \\
\text { Index }\end{array}$} & \multirow{2}{*}{$\begin{array}{l}\text { Allocation } \\
\text { Index by } \\
\text { Funding } \\
\text { Category }\end{array}$} \\
\hline & Lib. & Pub. & Lib. & Pub. & Lib. & Pub. & Lib. & Pub. & \\
\hline Health Sc. & 217 & 190 & 363 & 298 & 426 & 310 & 252 & 203 & 399 \\
\hline Humanities & 207 & 194 & 490 & 378 & 426 & 347 & 279 & 223 & 560 \\
\hline Pure Sc. & 225 & 171 & 400 & 365 & 388 & 360 & 319 & 315 & 502 \\
\hline Social Sc. & 229 & 182 & 419 & 313 & 399 & 308 & 237 & 199 & 360 \\
\hline
\end{tabular}

-Price Index $=\frac{t_{\mathrm{s}}}{t_{0}}=\frac{1979 \text { Prices }}{1971 \text { Prices }}$

material-related goods and services has increased sharply in the past years as revealed in figure 1. This tendency becomes even more noticeable when libraries are buying a large proportion of foreign titles because of the weakened Canadian dollar.

For many years, most libraries have benefited from the subscription-agency services because agents would receive substantial discounts from the publishers and would pass part of those reductions to the libraries. However, discounts to vendors seem to have been trimmed down and therefore agents are forced to charge more to libraries. In that context, the economic role of intermediaries should be reexamined to avoid paying excessive costs for currency exchange rates, address changes, postage services, and other handling charges. There exists a simple scheme that institutions must uncover to avoid paying twice for foreign money conversions. For example, a Belgian agent could buy materials from France with French francs and ask the institution to get paid in Belgian francs; obviously, this double foreign currency conversion is likely to be costly. This year, the Université de Montréal Library is buying more than ever directly from the publishers in an attempt to reduce these extra charges. Still, certain periodicals and monographs, mainly from France, are available only through agencies. Also, there is an educated sentiment among librarians that when services provided by agencies are taken away, the regular library staff picks up the slack. Of course, this situation might result in greater productivity or it might give rise to additional personnel demand. In the latter case, salary increases of the past few years would probably provide enough incentives to examine the economic consequences of dropping subscription agencies.
The toughest assignment that librarians have to carry out now is the preservation of collection development. As reported by White and Fry, ten years ago libraries were spending twice as much on books as on periodicals. ${ }^{38}$ Today, more acquisition dollars are being spent on periodicals even though the number of titles is on a downward slope in both categories. In many cases, this convenient shifting of dollars has allowed many libraries to maintain their current level of periodical holdings and to postpone the often unpopular but necessary decisions about canceling triplicate, duplicate, and even single subscriptions. While many libraries were faced with this problem in the mid-'70s, it seems that this phenomenon has become more acute at the Université de Montréal, in the late '70s. How does one go about deciding to renew a subscription instead of purchasing a book? Generally, the line of reasoning is based on the belief that periodicals are the main sources of research. Studies indicate that these decisions must be made on a subject-by-subject basis, as the importance of journals over books cannot be assumed. ${ }^{39,40}$

When confronted with tighter budgets, librarians' favored actions have generally been the following: (1) cut down on the placement of titles not previously owned; this seems to be an easier decision than to drop a subscription that has been automatically renewed for years, no matter the degree of evaluation made on the periodical collection; (2) cancel duplicate subscriptions; this action gives credence to the belief that collection continuity is rated above information use; (3) delete foreign periodicals, mainly those published in languages other than English. ${ }^{41}$ These are the posterior criteria that practice has put in the forefront. It is suggested that few librarians and institutions would approve of these 
$1971=100$

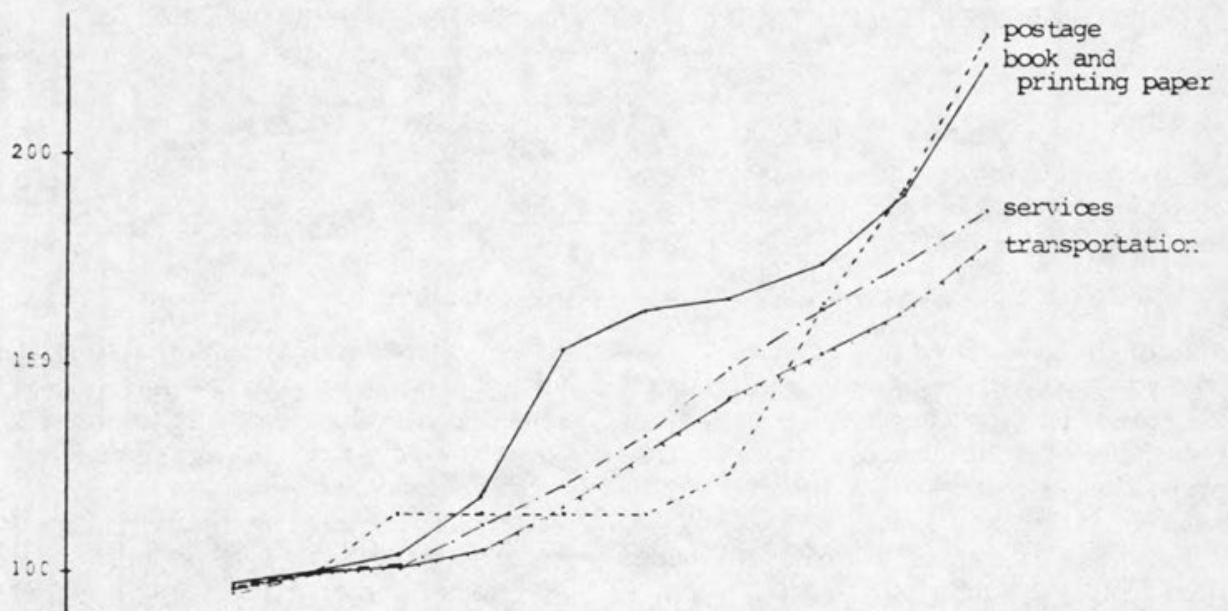

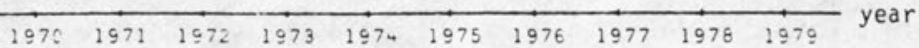

Fig. 1

Canadian Consumer Price Indexes for Specific Commodities

guidelines if they were told to apply them. However, dissenters have little choice but to find more rational and equitable ways to allocate diminishing funds to academic departments.

\section{CONCLUSIONS AND IMPLICATIONS}

This study produced the following major findings: (1) a drastic shift of library funds from books to periodicals has occurred in the past ten years; despite this transfer, the number of titles is declining in both categories; (2) foreign periodical titles, which constitute the overwhelming proportion of subscriptions at the Université de Montréal, put a severe financial stress on the library budget; (3) periodical prices actually paid by the library are higher than those advertised by publishers, because of factors such as subscription agencies, postal costs, international exchange rates, and other handling services; and (4) if cost and resource allocation studies are to be conducted with a reasonable amount of accuracy and investment in staff time, the present database cannot be used.

Assuming that the drifting of funds from books to periodicals was a temporary measure, the library management is heading for major decisions about which periodical titles should be continued and which should be deleted. Although no formulas are available to make these decisions, a manageable information system capable of providing, on request, hard data on basic questions such as the number and price of domestic and foreign titles by discipline and of establishing relationships 
with other variables such as the number and level of students, is a sine qua non to equitable resource allocation to academic unit and collection evaluation. Because of the high proportion of foreign titles purchased by the library, it is also suggested that an in-depth study be undertaken to examine the economic role of subscription agencies.

\section{REFERENCES}

1. Frederick C. Lynden, "Sources of Information on the Costs of Library Materials," Library Acquisitions: Practice and Thoery 1:105-16 (1977).

2. Richard W. Boss, "The Library as an Information Broker," College \& Research Libraries 40:136-40 (March 1979).

3. Miriam A. Drake, "Forecasting Academic Library Growth," College \& Research Libraries 37:53-59 (Jan. 1976).

4. H. William Axford, "Performance Measurement Revisited," College \& Research Libraries 34:249-57 (Sept. 1973).

5. Thomas J. Pierce, "An Empirical Approach to the Allocation of the University Library Book Budget," Collection Management 2:39-56 (Spring 1978).

6. Arthur M. McAnally, "Budgets by Formula," Library Quarterly 33:159-71 (April 1963).

7. Miriam A. Drake, "Attribution of Library Costs," College \& Research Libraries 38:514-19 (Nov. 1977).

8. Maurita Peterson Holland, "Serials Cuts vs. Public Service: A Formula," College \& Research Libraries 37:543-48 (Nov. 1976).

9. Richard DeGennaro, "Escalating Journal Prices: Time to Fight Back," American Libraries 8:69-74 (Feb. 1977).

10. James A. Thompson and Michael R. Kronenfeld, "The Effects of Inflation on the Cost of Journals on the Brandon List," Medical Library Association Bulletin 68:47-52 (Jan. 1980).

11. Monique Lecavalier, "L'Augmentation des Coûts des Publications en Série, les Budgets des Collections et le Développement," Argus 9:13-19 (Jan.-Feb. 1980).

12. Marion T. Reid, "Coping with Budget Adversity: The Impact of the Financial Squeeze on Acquisitions," College \& Research Libraries, 37:266-72 (May 1976).

13. Herbert S. White, "Publishers, Libraries, and Costs of Journal Subscriptions in Times of Funding Retrenchment," The Library Quarterly 46:359-77 (1976).

14. Verner W. Clapp and Robert T. Jordan, "Quantitative Criteria for Adequacy of Academic Library Collections," College \& Research Libraries, 26:371-80 (Sept. 1965).

15. William E. McGrath, Ralph C. Huntsinger, and Gary R. Barber, "An Allocation Formula Derived from a Factor Analysis of Academic
Departments," College \& Research Libraries 30:51-62 (Jan. 1969).

16. S. K. Goyal, “Allocation of Library Funds to Different Departments of a University - An Operational Research Approach," College \& Research Libraries 34:219-22 (May 1973).

17. William E. McGrath, "A Pragmatic Book Allocation Formula for Academic and Public Libraries with a Test for Its Effectiveness," $L i$ brary Resources \& Technical Services 19:356-69 (Fall 1975).

18. William E. McGrath, "Relationships between Hard/Soft, Pure/Applied and Life/Nonlife Disciplines and Subject Book Use in a University Library," Information Processing \& Management 14:17-28 (1978).

19. Ellis Mount and Paul Fasana, "An Approach to the Measurement of Use and Cost of a Large Academic Research Library System: A Report of a Study Done at Columbia University Libraries," College \& Research Libraries 33:199-211 (May 1972).

20. Steven D. Gold, "Allocating the Book Budget: An Economic Model," College \& Research Libraries 36:397-402 (Sept. 1975).

21. Joseph J. Kohut and John F. Walker, "Allocating the Book Budget: Equity and Economic Efficiency," College \& Research Libraries 36:403-10 (Sept. 1975).

22. Drake, "Forecasting Academic Library Growth."

23. Steven Leach, "The Growth of Major Academic Libraries: Rider and Purdue Reviewed," College \& Research Libraries 37:531-42 (Nov. 1976).

24. W. Goffman, "Bradford's Law Applied to the Maintenance of Library Collections," in T. Saracevic, Introduction to Information Science (New York: Bowker, 1970).

25. Eugene Garfield, "Significani Journals of Science," Nature 264:609-15 (Dec. 16, 1976).

26. Pierce, "An Empirical Approach to the Allocation of the University Library Book Budget."

27. F. F. Clasquin, "Periodical Prices 1977-79 Update," Library Journal 104:2168-71 (Oct. 15, 1979).

28. "Periodicals Prices," Library Association Record 81:232-33 (May 1979).

29. Sally F. Williams, "Construction and Application of a Periodical Price Index," Collection Management 2:329-44 (Winter 1979).

30. Norman B. Brown and Jane Phillips, "Price 
Indexes for 1979 - U.S. Periodicals and Serial Services," Library Journal 104: 1628-33 (Sept. $1,1979)$.

31. John P. Dessauer, "U.S. Consumer Expenditures on Books in 1978," Publishers Weekly 217:41-42 (Feb. 1, 1980).

32. Brown, "Price Indexes for 1979 - U.S. Periodicals and Serial Services."

33. Ulrich's International Periodicals Directory (New York: Bowker, 1979).

34. White, "Publishers, Libraries, and Costs of Journal Subscriptions in Times of Funding Retrenchment."

35. Williams, "Construction and Application of a Periodical Price Index."

36. White, "Publishers, Libraries, and Costs of Journal Subscriptions in Times of Funding Retrenchment."
37. Ibid.

38. Herbert S. White and Bernard M. Fry, "Economic Interaction between Special Libraries and Publishers of Scholarly and Research Journals - Results of an NSF Study," Special Libraries 68:109-14 (March 1977).

39. Harry M. Kriz, "Subscriptions vs. Books in a Constant Dollar Budget," College \& Research Libraries 39:105-9 (March 1978).

40. McGrath, "Relationships between Hard/Soft, Pure/Applied, and Life/Nonlife Disciplines and Subject Book Use in a University Library."

41. Herbert S. White, "The Economic Interaction of Scholarly Journal Publishing and Libraries during the Present Period of Cost Increases and Budget Reduction," The Serials Librarian 1:221-30 (Spring 1977). 